\title{
IMPLEMENTATION OF IMMUNIZATION SERVICES FOR THE UNDER-FIVE CHILDREN DURING COVID-19 PANDEMIC AT TWANO COMMUNITY HEALTH CENTER, JAYAPURA
}

\author{
Goklian Paraduan Haposan, Pujiyanto
}

\author{
Universitas Indonesia
}

\begin{abstract}
Background: Immunization service is essential in reducing infant mortality rate. However, due to physical distancing and social distancing, the Covid-19 pandemic may have reduced the utilization of immunization service. This study aimed to determine the implementation of immunization services for the under-five children during Covid-19 pandemic at Twano community health center, Jayapura.

Subjects and Method: This was a qualitative study conducted at the Twano Entrop Community Health Center, Jayapura City, Papua, from August to September 2020. A sample of informants including immunization personnel and head of community health center. The data were collected by in-depth interview, questionnaire, and document review.

Result: The immunization coverage was $43 \%$ at Twano community health center, which was far below the national target of $80 \%$. The factors affecting immunization coverage included: (1) worries of infection; (2) parental ignorance; (3) no invitation from the health workers.

Conclusion: The factors affecting immunization coverage included are worries of infection, parental ignorance, and no invitation from the health workers.
\end{abstract}

Keyword: immunization, the under-five children, Covid-19 pandemic.

Correspondence:

Goklian Paraduan Haposan. Faculty of Public Health, University of Indonesia. Pondok Cina, Beji district, Depok city, West Java 12345. Email: goklianofm@gmail.com.

Mobile: o81344237365.

The $7^{\text {th }}$ International Conference on Public Health

Solo, Indonesia, November 18-19, 2020 | 127 https://doi.org/10.26911/the7thicph.02.16 